\title{
Hydro geochemical Characterization of Surface Water Sources in Owerri Capital Territory, Southeastern Nigeria
}

\author{
${ }^{1}$ Akakuru, Obinna C., ${ }^{2}$ Maduka, Eric C., and ${ }^{3}$ Akakuru, Ozioma U. \\ ${ }^{1 \& 2}$ Department of Geography and Environmental Studies, Alvan Ikoku Federal College of Education, Owerri. \\ ${ }^{3}$ Department of Chemistry, University of Benin, Benin City.
}

\begin{abstract}
The Owerri Capital Territory is predominantly underlain by the Benin Formation (the coastal plainsands) the major rock types include sands, sandstone, and gravel with clay occurring as lenses. Hydrogeochemical evaluation of surface water sources in the area involved the assessment of the physicochemical and bacteriological analyses. This was achieved through water sample analysis. The result of the analysis revels that $\mathrm{Fe}^{2+}, \mathrm{Pb}^{2+}, \mathrm{SO}_{4}{ }^{2-}, \mathrm{Cd}^{2+}, \mathrm{Zn}^{2+}$ concentration $(\mathrm{mg} / \mathrm{l})$ ranges between 0.08-0.38, 0.03 $0.09,3.0$ - 4.0, 0.029 - 0.061, 0.06-0.68 respectively. The hydrochemical facie Classification result of the water samples show the predominance of alkali bicarbonate water type $\left(\mathrm{Na}^{+}+\mathrm{K}^{+}\right)-\mathrm{HCO}_{3}^{-}$that is largely soft and therefore, mostly of acceptable quality for household uses. Surface water sources are predominantly infected with microbial contamination, indicating input of organic (faecal) wastes in the flow system. Water resources development in the area requires elaborate qualitative assessment, to ensure that any necessary pre-use treatment is affected.
\end{abstract}

Keywords: Hydro geochemical, Pollution, Surface Water, Water Classification.

\section{Introduction}

Domestic and industrial discharges into surface water bodies vary in nature, quality and quantity, thus contributing significantly to chemical, biological and physical pollution of these water bodies. Most of these pollutants enter the streams and rivers and are transported downstream passing through regional and international water bodies carrying with them wastes whose quality and quantity are yet to be determined.

The desirability of water resources evaluation becomes most evident when it is recalled that the resource is heavily impacted by both natural and anthropogenic pollution incidences. Todd (1980) noted that the natural environment can easily adjust and remain in harmony with natural pollution factors but anthropogenic pollution incidents are usually violent, and the environment needs to be regularly monitored to establish the magnitude of damage done.

Owerri Capital Territory is one the new urban centres of Nigeria with rapid growth in population, urbanization and industrialization. Consequently, regular evaluation of water quality is of fundamental importance because about 95 percent of the inhabitants of Owerri Capital Territory rely on groundwater sources for daily water needs and surface water sources plays a significant role in the hydrological cycle.

\section{Location of The Study Area}

The study area comprises Owerri Municipal, parts of Mbaitoli, Ikeduru, Owerri West and Owerri North Local Government Areas that make up the Capital Territory. It lies between latitudes $5^{\circ} 24^{1}$ and $5^{\circ} 35^{1} \mathrm{~N}$ and longitudes $6^{\circ} 56^{1}$ and $7^{\circ} 08^{1} \mathrm{E}$, covering an area of about $740 \mathrm{~km}^{2}$. The area is predominantly low-lying with a good road network (Fig. 1). Ezeigbo (1987) observed that Nigeria experiences high temperatures all year round because of its latitudinal location within the tropics. In the study area, the mean annual temperature of $27^{\circ} \mathrm{C}$ has been recorded. The terrain is characterized by two types of landforms namely, the highly undulating ridges in the northeast and nearly flat topography in the southwest (Ibe et al., 2007).

\section{Hydrology}

The study area is drained by Rivers Otamiri, Nworie, Mbaa and Okitankwo with peak discharge occuring in September and October (Ezeigbo, 1987). Surface water hydrology plays an important role, as it enhances groundwater recharge potential and determines water balance and hydrologic safe yields of aquifers. 


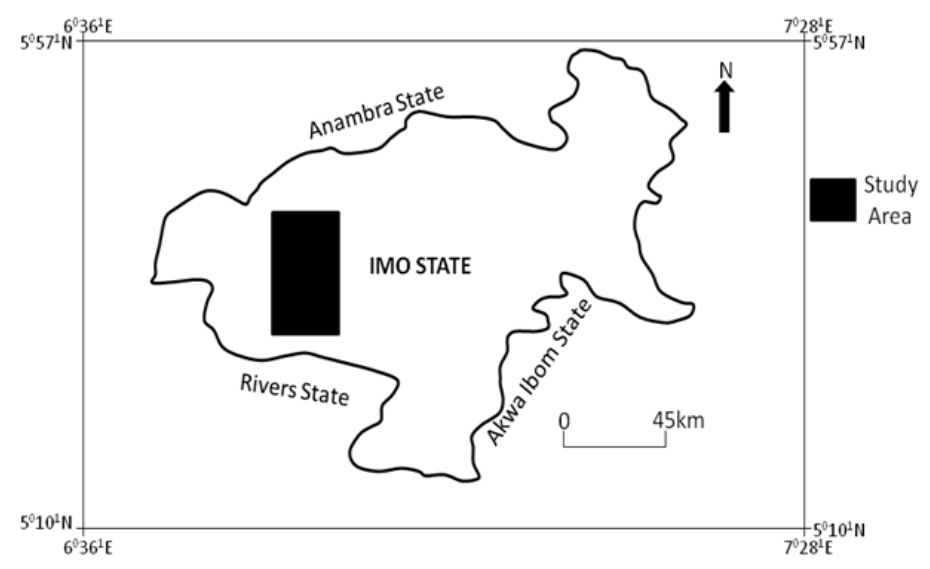

Fig. 1: Map of Imo State showing the study area.

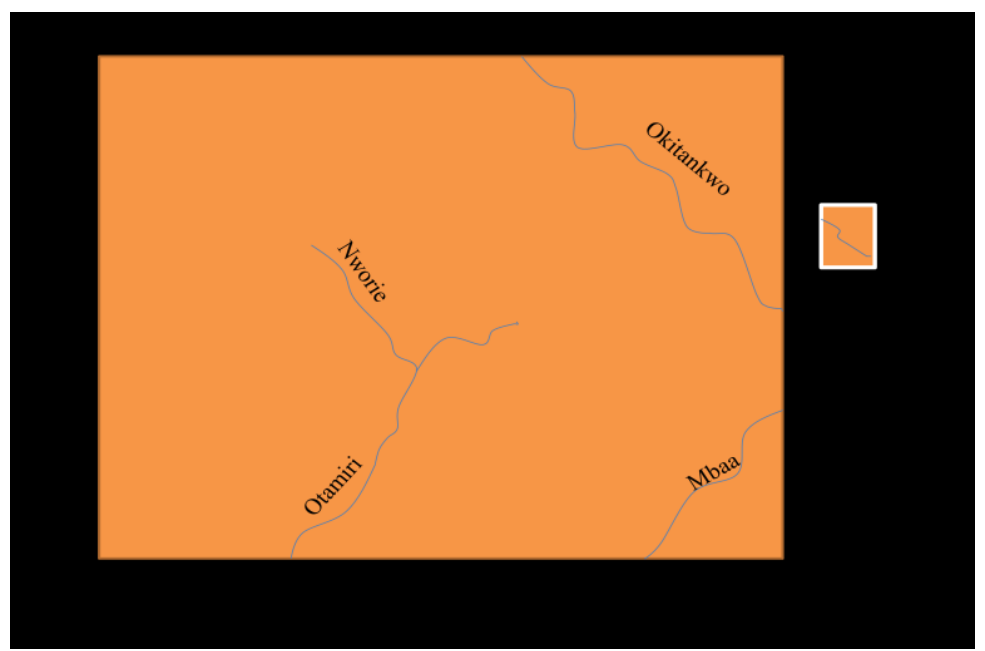

Fig 2: Surface water sources (Drainage Pattern) in the Study Area

\section{Method Of Investigation}

The study was effectively done through literature review, fieldwork, sample collection and preservation, analysis and data processing. Two (2) water samples were collected from each water source, making a total of eight (8) samples from surface water sources. Plastic containers of one liter labeled 1-20 thoroughly washed and rinsed with the water to be collected were used. On collection, dilute hydrochloric acid $(\mathrm{HCl})$ were used to stabilize the samples for the determination of cations. All the samples were preserved by refrigeration and analyzed within 24hours of collection. The analyses were carried out in accordance with American Public Health Association Standard (1992). Spectrophotometric method was used to analyze for cations and anions. The physical parameters were analyzed with thermometer, $\mathrm{pH}$ meter, Turbidimeter and Colour comparator discs. The microbial analysis was done using the filter membrane method and each sample was incubated for at least 24hours.

\section{Water Quality}

This study assesses the water resources, with particular reference to quality. Some physical, chemical and biological parameters of the surface water samples collected from different locations in Owerri Capital Territory were examined in relation to World Health Organization (WHO), (2006) permissible standard for drinking water. Also, Piper Trilinear diagram and Schoeller semi logarithmic diagram were used to classify the chemical composition of the samples collected hence, determine the predominate water type(i.e. dominant ionic specie).

\section{Results and Discussions}

The result revealed that the appearance and colour of the samples are not clear (10/15). Majority of the samples are odourless, though some objectable odour was observed in some surface water. $\mathrm{pH}$ values range from 7.5 - 10.7. According to the World Health Organization (2006), health effects are most pronounced in $\mathrm{pH}$ extremes. Drinking water with an elevated $\mathrm{pH}$ (above 11) can cause skin, eye and mucous membrane irritation. 
PH values below 4 can have corrosive effects of low pH levels. Conductivity values range from 0.07 $0.2 u \mathrm{~s} / \mathrm{cm}$. Conductivity is a measure of the total dissolved ionic constituents in water and it varies with temperature. Total Dissolved Solids (TDS) values range from $52.5-67.1 \mathrm{mg} / 1$. Total Hardness values ranges from $2.2-6.2 \mathrm{mg} / \mathrm{l}$. The TDS values in the water samples are far below the WHO permissible limits, thus indicating good quality. TDS is the quantitative measure of the sum total of organic and inorganic solutes in water.

Chloride concentration ranges from $2.1-5.2 \mathrm{mg} / 1$, while sulphate and nitrate values range between 3.0 $-4.0 \mathrm{mg} / \mathrm{l}$, and $2.0-2.2 \mathrm{mg} / \mathrm{l}$, respectively. The chloride, sulphate and nitrate concentration levels in the study area fall below the WHO (2006) recommended highest permissible limit for drinking water, thus indicating good quality. Generally, nitrate content shows very low values, with undetectable values in some samples. Concentration level is below WHO recommended highest permissible limit indicating good quality. Assessment of nitrate concentration in water is important. Values over $50 \mathrm{mg} / \mathrm{l}$ are dangerous to babies as it could lead to the problem of infantile cyanosis or "Blue blood" which could result to death (Chapman, 1992).

The bicarbonate concentration values range between $24.6-28.6 \mathrm{mg} / \mathrm{l}$. The most important effect of bicarbonate ingestion is the change in acid-base balance as well as blood $\mathrm{pH}$ and bicarbonate concentration in biological fluids. Water which contains bicarbonate $(>600 \mathrm{mg} / \mathrm{l})$ may have an effect on acid-base balance.

Zinc concentration falls within the range of $0.06-0.68 \mathrm{mg} / \mathrm{l}$. The zinc concentration of all the samples fall below the WHO permissible and maximum permissible limits .This indicates relatively good quality. Copper concentration falls within the range of $2.19-2.88 \mathrm{mg} / \mathrm{l}$. This indicates water of relatively good quality.

Cadmium concentration falls within the range of $0.029-0.052 \mathrm{mg} / \mathrm{l}$. Lead concentration falls within the range of $0.03-0.09 \mathrm{mg} / \mathrm{l}$. Results of bacteriological analysis of the water samples show that the surface water sources are contaminated with fecal coliform. The values of total microbial load and total coliform in surface water sources indicate poor quality for domestic water supplies. Table 1 shows Summary of physicochemical and bacteriological analyses results of water samples from the study area.

Table 1: Physicochemical and bacteriological analyses results of water samples from the study area.

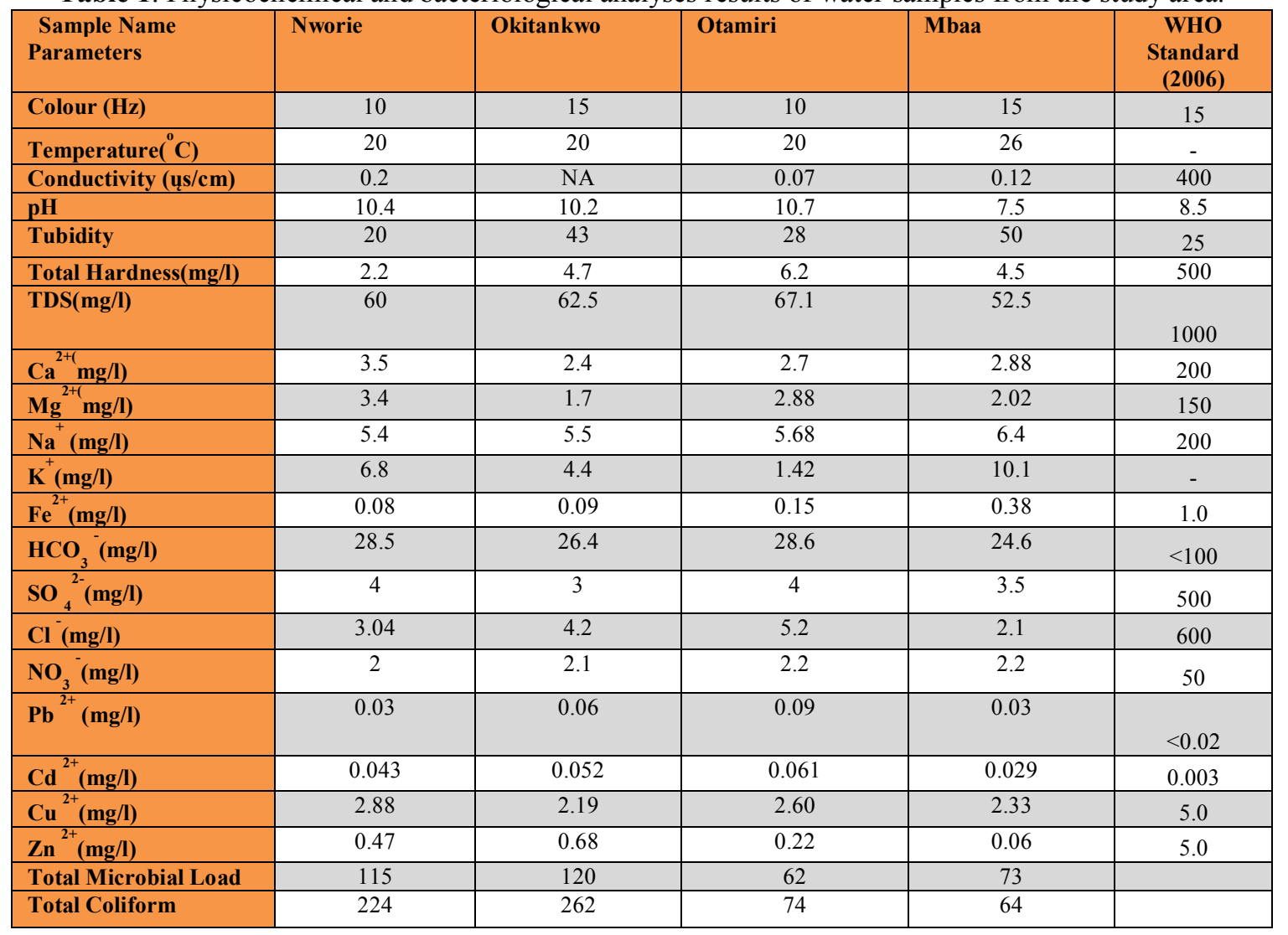




\section{Water Classification}

The chemical composition of water varies considerably. From the Piper trilinear diagrams and Schoeller semi logarithmic diagram (Figs. 3\&4), the dominant water type is alkali bicarbonate water type, with bicarbonate as the predominant ion. The dominance of alkali bicarbonate water type could be attributed to the infiltration of carbon dioxide rich rainwater derived from the atmosphere and input of alkali salts from anthropogenic sources. The Piper trilinear plots conform to Schoeller semi logarithmic plot (Fig 4); both indicating predominance of alkali-bicarbonate water type.

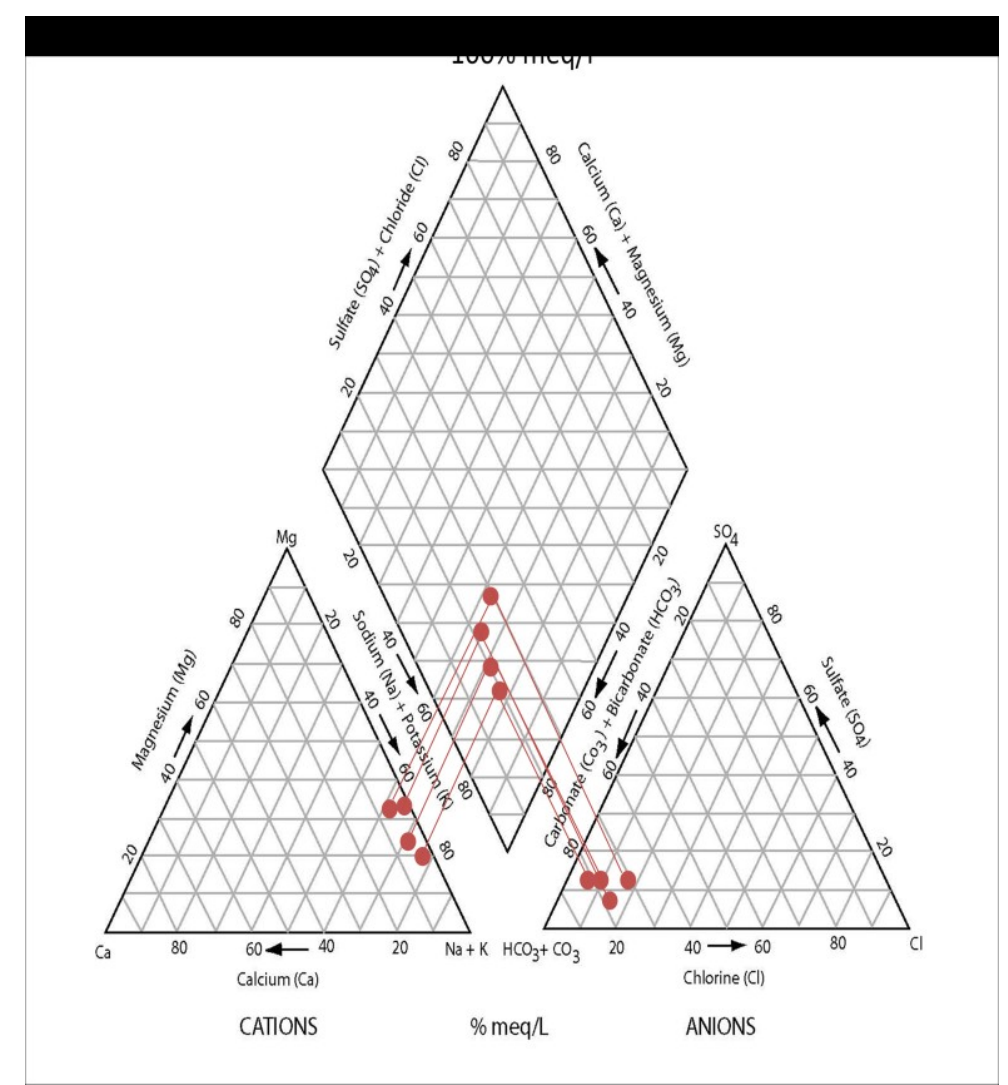

Fig. 3: Piper trilinear diagram showing the water types of the surface water sources in the study area.

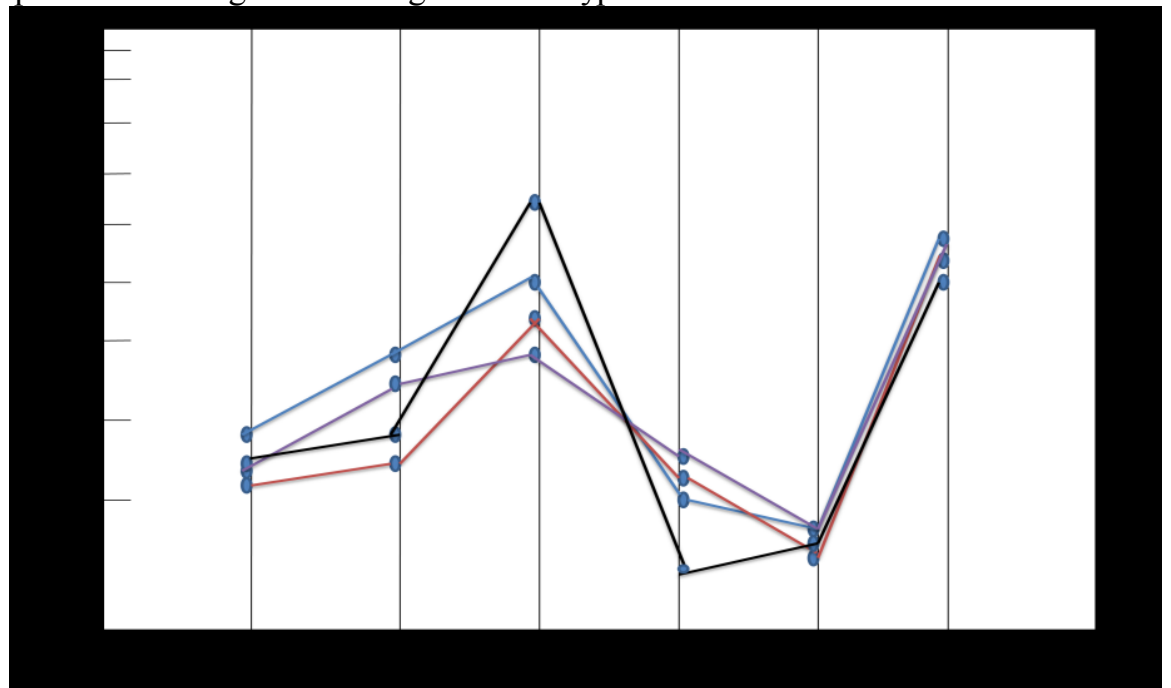

Fig. 4: Schoeller semi logarithmic diagram showing the water types of the surface water sources in the study area. 


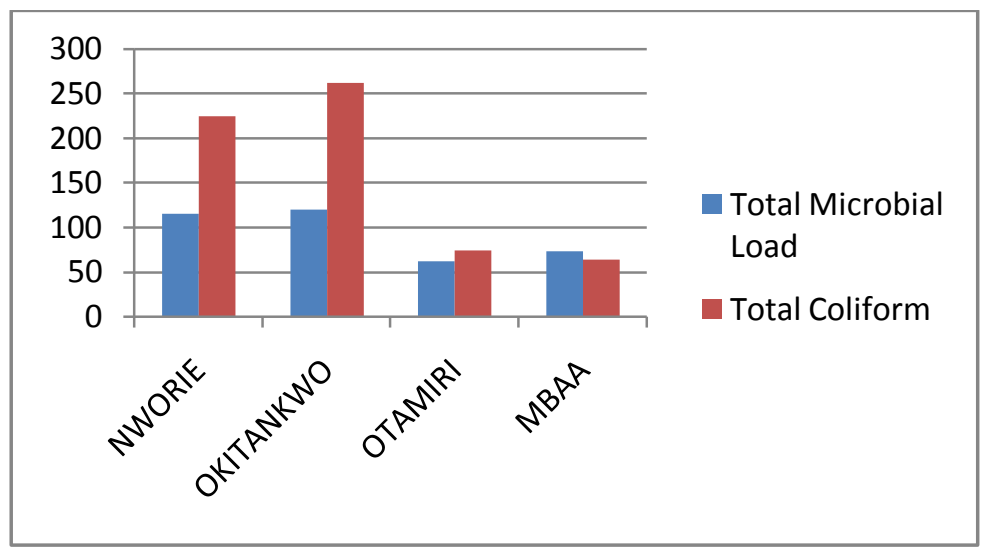

Fig. 5: Bar chart showing microbial constituents in the water samples analyzed

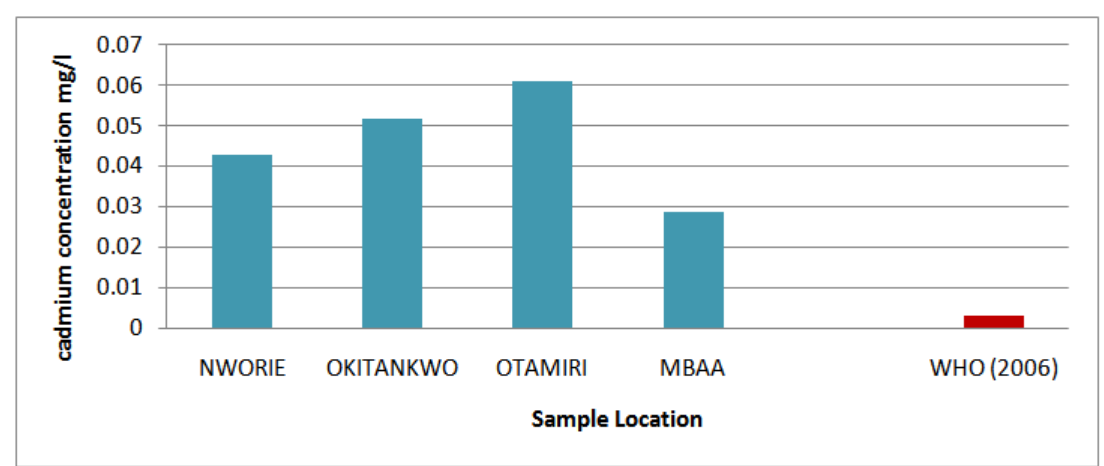

Fig. 6: Bar-chart showing cadmium concentration in the water samples analyzed $\mathrm{WHO}=$ World Health Organization

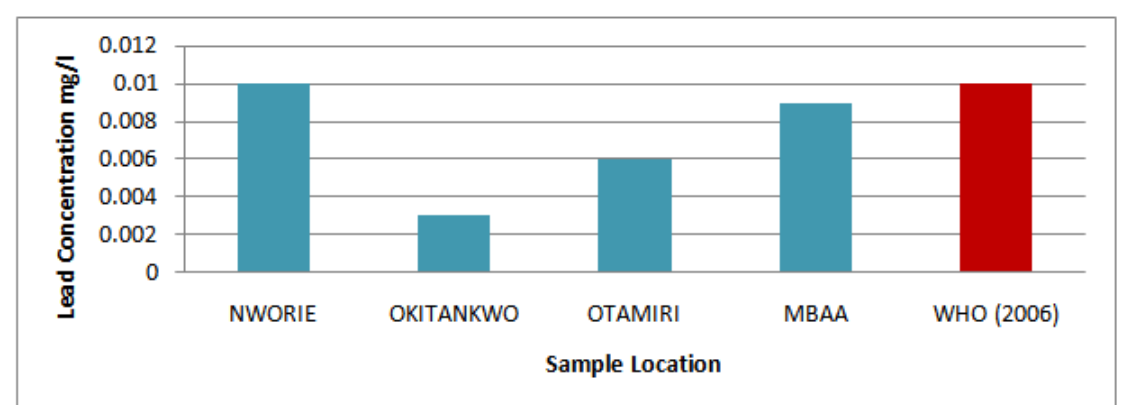

Fig. 7: Bar-chart showing lead concentration in the water samples analyzed $\mathrm{WHO}=$ World Health Organization

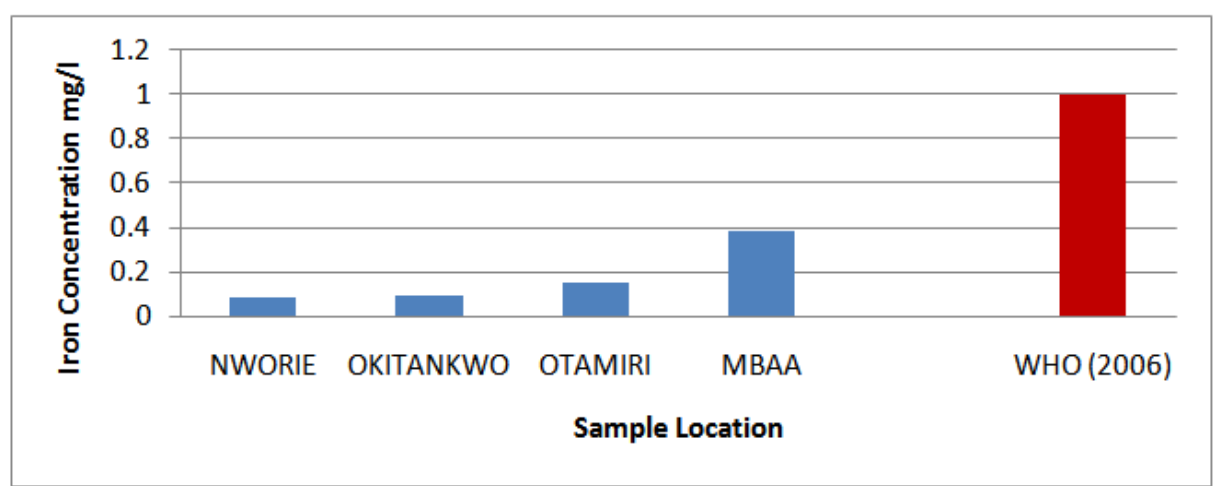

Fig. 8: Bar-chart showing iron concentration in the water samples analyzed $\mathrm{WHO}=$ World Health Organization 


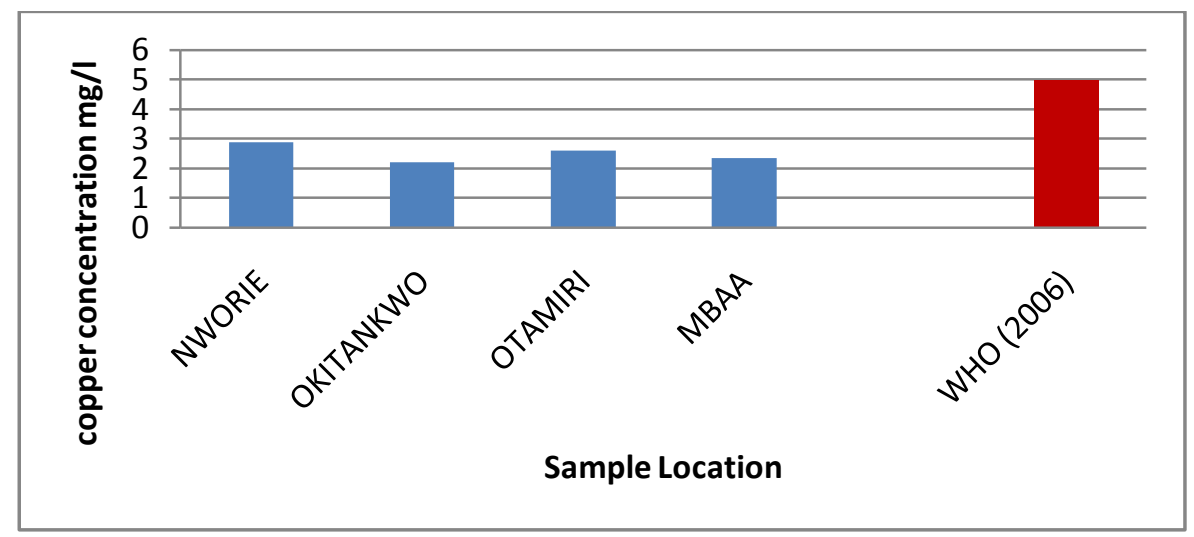

Fig. 9: Bar-chart showing copper concentration in the water samples analyzed $\mathrm{WHO}=$ World Health Organization

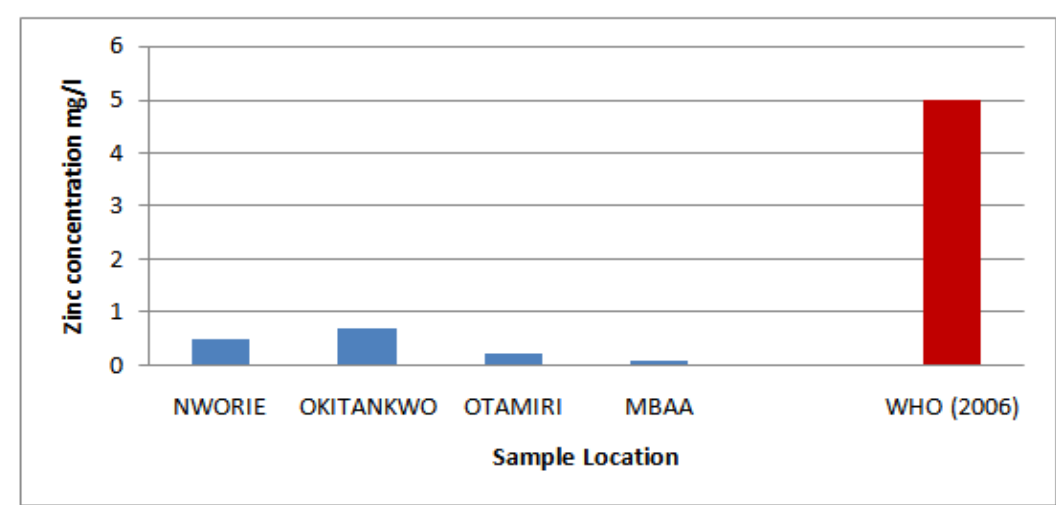

Fig. 10: Bar-chart showing Zinc concentration in the water samples analyzed $\mathrm{WHO}=$ World Health Organization

\section{Conclusion}

The hydrogeochemical characterization of surface water sources of Owerri Capital Territory has been done; the results of the investigation reveal certain attributes:

Results of water quality analysis compare favourably with WHO (2006) standards for drinking water. Some important water quality problems identified in parts of the study area are high concentrations of Turbidity, $\mathrm{pH}$, lead $(\mathrm{Pb})$, and cadmium $(\mathrm{Cd})$ which may have adverse pathogenic consequences. Bacteriological analysis of surface water sources is predominantly objectable. This shall be of great concern to various agencies and arms of government linked with water supply to the population since the surface water sources constitute a common and affordable source of water supply to the less privileged group of the population.

Results of hydrochemical analysis of water samples show the predominance of alkali bicarbonate water type that is largely soft. Based on the chemistry, the water is considered acceptable for many household uses except for drinking purposes where pre-use treatment is required.

\section{Recommendations}

1. There is need for regular appraisal of the available water resources by water managers and planners to ascertain the quality of the resource. Though the availability of the resources is relatively assured, quality sustainability should be a priority.

2. Adequate legislative measures should be in place to ensure that environmental standards are observed while embarking on various private, commercial and industrial activities in the area.

3. Public enlightenment efforts need to be enhanced in the entire area, especially in densely populated urban area, to improve on personal and public hygienic lives of the people. Efforts in this direction can reduce the problems of microbial pollution/contamination in public water supply sources. 


\section{References}

[1]. APHA,. Standard Methods for Examiantion of Water and Water, $18^{\text {th }}$ Edition. American Public Health Association (APHA), American Water Works Association (AWWA), Washington D.C., 1992 pp.50-54.

[2]. Chapman. D Chapman and Hall Ltd, 2-6 boundaries Row, London: SEI BHN. 1992.pp 99- 187.

[3]. Egboka, B.C.E. Hydrogeological Provinces of Nigeria. In Water Quality Bull. 13, No. 4, 1988, pp. 117-125.

[4]. Ezeigbo, H.I. Quality of Water Resources in Anambra State. Nigeria. Jour. Min.Geol., vol 23, 1987 , pp.97 - 103.

[5]. Ibe, K.M., Nwankwor, G.I. and Onyekuru, S.O. 2007, Assessment of Ground Water Vulnerability and its Application to the Development of Protection Strategy for the Water Supply Aquifer Owerri, South-eastern Nigeria; Jnl. of Env. Environ Mon and Assess 67: $323-360$.

[6]. Piper, A.M. A Graphic Procedure in the Geochemical Interpretation of Water Analysis. Trans Am Geophys. Union 25:1944 pp.914923.

[7]. Todd, D.K. and Mays, L.W. Groundwater Hydrology, $3^{\text {rd }}$ Ed. John Wiley and Sons, Inc. New York, 1980 pp.267 - 315.

[8]. Uma, K.O. and Egboka, B.C.E. (1985). Water Resource of Owerri and its environs. Imo State, Nigeria. J. Min. Geol.22 (1-2): 57 64.

[9]. IT'S Guidelines for Drinking Water Quality. Geneva: World Health Organization, 2006, pp.130 - 185. 